\title{
Chapter 25 \\ Embodied Signs: Expanding Representations Through and with Bodies
}

\author{
Beth Lewis Samuelson and Karen E. Wohlwend
}

This chapter highlights the emerging research on literacy and embodiment, suggesting that a semiotic perspective is urgently needed to understand how embodiment blurs binaries such as language and action or text and context through (1) representations of bodies and (2) representations with bodies. We draw on this view of embodiment to expand the definition of text, critical for understanding signs that are increasingly produced within collaborative and immersive interactions with global scapes that are both material and textual (Appadurai 1996). Such text/context blurrings are situated in social practices and fluid contexts such as transnational literacy flows and play worlds. This notion of embodiment has long been present in semiotics, but is now emerging as a powerful lens to advance literacy studies. Although it is possible to look at multimodal texts of all sorts, including texts of body, the embodiment of meaning through representations of the body and representations through the body is often just a potentiality or a possibility, a data source that is available for selection, whereas we see it as central to the enterprise. Embodied meaning is a rich source for semiotic analysis drawn from historical, sociocultural, and cognitive perspectives on bodily practice in daily life and daily learning, and through children's play.

\subsection{Representation Through Bodies}

Historically, embodiment has been a silent partner in semiotics, for instance, it was present in the abstract notions of frame (Goffman 1981) and of participation frameworks (Gumperz 1982), but with the rough edges of the particulars smoothed away

\footnotetext{
B. L. Samuelson $(\bowtie) \cdot$ K. E. Wohlwend

Indiana University Bloomington, Bloomington, IN, USA

e-mail: blsamuel@indiana.edu

K. E. Wohlwend

e-mail: kwohlwen@indiana.edu

(C) Springer Science+Business Media Dordrecht 2015

P. P. Trifonas (ed.), International Handbook of Semiotics,

DOI 10.1007/978-94-017-9404-6_25
} 
for the sake of getting to object to be studied: the interaction. Bourdieu considered language to be a whole body activity: "Language is a body technique" (1991, p. 86), and he inscribed the body into semiotics through his notion of habitus, which he fixed in the body, intimately connecting the body-as-text to the social and cultural fields in which it was formed. In a less-direct way, Bakhtin (1986) also laid a framework for embodiment when he turned his back on the idea that poetic language is by and large a formal system, and a special one at that. By asserting that genres are grounded in the social practices of production and reception, Bakhtin gave them a commonplace aspect, as everyday as the body, and showed that they are dependent on and embodied by concrete works. We can think of concrete works as actual language or literacy events, and much productive work has been achieved by this perspective. What is more concrete than the material world, including the bodies, and representations of bodies, that are so critical for all communicative activity?

Linguistic anthropology has long recognized the critical importance of the bodyas-text. The study of indexicals in ethnography of communication (Hymes 1995) provides as a means of teasing out the "habituation of perspectives" that forms Bourdieu's notion of the habitus. Deictics such as I, you, we, they, here, there are "inherently relational," giving a concrete aspect to critical concepts such as inclusion, exclusion, proximity, and distance to objects and other persons (Hanks 1996, p. 162). Deictics are connected to the bodies of the actors and change their meaning with each token, like facets in a diamond turning in the sunlight, such that bodily hexis, orientation in space and time, direction of gaze, physical attributes such as age and height, particularities of dialect and idiolect, and myriad other aspects of the physical presence of the actors can be recorded by studying the orientation of each indexical, as it is made concrete, "always a matter of the relation between the utterance, the situation in which it is produced, and the object being talked about" (p. 162). Hanks adopted an apt grammatical metaphor for describing the embodied nature of communicative practice when he asserted that "context saturates linguistic form, right down to the semantic bones" (Hanks 1996, p. 142). The importance of the embodied emerges also in ventriloquation, which shows how students and teachers use indexicals in reported speech to mitigate uncomfortable situations in which student texts must be publicly critiqued; the indexicals project distance and allow the actors to take on imagined roles (Samuelson 2009). Indexicals provide a window through which the investigator can follow the gaze of the actor, to see that mediated world as the actor sees it.

From cognitive linguistics, the details of mundane bodily existence yield critical insights into the emergence of semiosis. The small stories of "events in space" (Turner 1996, p. 13) that humans execute daily - a child pointing to a favorite toy, a man pouring a cup of coffee, a woman petting a dog - are overlooked precisely because they are so commonplace, and yet they form the basis of predictability that allows meaning-making to occur. In second language studies, language-learning memoirs in which students employ physical metaphors and imagery, linking emotions, feelings, dispositions, connections to environment, and to the storying self, suggest that learning a language is just as much a physical as an intellectual experience (Kramsch 2009), an "impulse" and "drive" for physical, social, and emotional 
balance rather than the pragmatic considerations of career advancement, integration into a new community, or even identifying with speakers of the language or their beliefs. The desire to learn to speak another language, Kramsch asserts, is not:

just a matter of interacting with the Other. It is rather, an appropriateness or coordination of bodies with themselves and their environment, language learners with themselves and the foreign language, non-native speakers with other non-native and with native speakers, teachers with their students. Appropriateness here is not just an adherence to pragmatic or social norms, but a deep coordination of body and mind, self and other. A better term might be relationality or synchronicity, in which the organism feels in sync with itself, its language, its environment and others. (p. 75-76)

In a transnational storytelling exchange, representations of the body through depictions of violence and death have elicited visceral reactions in the bodies of undergraduate women whose habitus did not permit the inclusion of such content matter in stories for children, suggesting that the taboo and the unmentionable topic are also embedded in body, inscribed into the habitus through interactions with field over time (Samuelson, in preparation).

\subsection{Play: Representation with Bodies}

In literacy studies, Siegel and Rowe (2011) draw upon the Peircian notion of indexicality to explain how meanings expand when emplaced and embodied by people in a concrete setting such as a classroom. Using the example of a kindergartner holding a book upside down, they show how the child's handling of the book, "What Can Go Up?" re-mediated the text through manual repositioning of the book in physical space; that is, the reader used his body in the immediate space to reverse the sign, transforming the text into a pretend book "What Can Go Down?" Siegel and Rowe argue that this action text extends beyond interaction with fixed material or linguistic properties of the printed book. Instead, such events enmesh texts in contexts as textual performances (assemblages of linguistic, visual, kinesthetic, and musical signs), discursive acts (practicing fluent reading of "just right" books with partners), and temporal (during readers' workshop) and spatial settings (in the block corner).

Representations with bodies engage production of played texts in contexts by emphasizing particular modal meanings through changes in body movements, postures, facial expressions, and proximity to co-players, furniture, props, and toys. In this way, even very young children's play creates complex embodied signs and action texts, not to compensate for their emergent language or to craft a polished text (Boldt 2006) but because they intend to produce engaging texts and rich play worlds to inhabit with others. Furthermore, bodies in/as texts/contexts take on additional layers in digital domains as meanings shift through virtual proximity among avatars, arrangement of layouts, and movement across screens and networks (Jones 2005).

New Literacy Studies (Gee 1996; Street 1995) recognize play as embodied ways of producing and wielding texts. Playing a text (Mackey 2007) is not a stance outside a text but embodies it from within the text itself. Importantly, play also creates 
and upholds a collaboratively pretend context with others. In this view, play is a social practice that uses bodies to represent meanings but also to participate in valued cultural practices (Ghiso 2011; Siegel et al. 2008; Wohlwend 2008).

Play is a particularly powerful means of sign-making that invites players to use bodies as the medium for conveying play narratives, imagined characters, in an imagined context through semiosis that merges with physical place and social relationships. New technologies and digital literacies have drawn our attention to the ways that play challenges structured notions of signified/signifier relationships around representations of body:

\begin{abstract}
Semiotics provides a method for studying how digital literacies make possible new ways of interacting with written signs. This form of meaning-making pivots on the player's ability to "be a representation" by projecting herself or himself sensorially into a game character, setting a new kind of stage for meaning-making. While reading and writing mediated by such technologies as cave painting, books, and billboards require a person to orient to the sign as a signifier, digital technologies have the unique affordance of enabling a person to orient to the sign as both signifier and signified. Within video games, for example, the reader becomes or inhabits a symbol, enabling him or her to interact with signs as if they are the very things they represent. (Steinkuehler et al.2005)
\end{abstract}

These as if conditions are a staple of play, whether digital or liveaction. During pretense, the sign-maker is simultaneously creating and enacting a played self-sign while producing actions in a played text and inhabiting a played context. Even very young children understand the sign-making potentials of toys and their own positioning as both players and pretend characters. In part, this is because toys are designed to clearly signal how they should be used in play (Brougère 2006). For example, dolls are identity texts (Carrington 2003) that signal both pretend characters (babies, princesses) and doll players (preschoolers, girls). In a 3-year ethnographic study of play in early childhood classrooms, Wohlwend examined how kindergartners played with toys and dolls as they wrote, and rewrote familiar Disney Princess fairy tales to craft more agentic storylines and roles such as a princess who saved herself and fought off the dragon (Wohlwend 2011b).

Mediated discourse theory (Scollon 2001), a blend of practice theory (Bourdieu 1977) and cultural-historical activity theory (Engeström1987; Leont'ev1977; Vygotsky1935/1978), is useful for examining embodiment in the fluid, inventive, and collaborative nature of pretend texts and shared meanings that children produce and negotiate when they play together. The emphasis in this approach is on meanings created through physical actions with material artifacts and multiple modes as indicators of historical practices and ideological discourses. Research using methods of nexus analysis (Scollon and Scollon 2004; Wohlwend 2011b) and multimodal mapping (Wohlwend 2011a) enables microanalysis of key modes (e.g., image, gaze, sound effect, proximity, layout) in the layered action texts and contexts (e.g., doll or avatar characteristics, production histories, marketing strategies, peer culture capital) that signaled particular player or character identities in media, peer, and school cultures. Using nexus analysis, Wohlwend examined how two 6-year-old boys blurred the gendered identities and discourses attached to Disney Princess dolls and films by pivoting among available identity texts in Disney Princess media products, including princess characters, body images, brand identity, peer relations, 
and school expectations (Wohlwend 2012). Mediated discourse analysis examined how boys blurred gender identity texts to engage their favorite princess media, to recruit other boys as players, and to participate as writers and players in the kindergarten classroom.

In addition to expanding identity texts, play merges here-and-now realities in a physical place with an imagined place, opening more possibilities for story actions and roles. Further, pretend contexts in childhood cultures are simultaneously local and global. Children's popular media fantasy worlds often come furnished with film narratives, video game storylines, and casts of characters, circulated through transmedia franchises of toys, clothing, food, and household goods that children consume daily. These franchises form pervasive artifactual networks, linked by narratives which children use as semiotic resources. For example, Marsh (2005) documented one preschool child's narrative web for Disney's Winnie the Pooh franchise that included stuffed toys, Duplo playsets, pajamas, lunchboxes, and books. The storied products anchored parent-child rituals such as bedtime routines that provided emotional security as well as literacy resources. Children's deep emotional attachments to characters in these franchises constitute an important element of embodiment as children enact favorite characters through proxies by animating dolls, action figures, and toys to replay and revoice familiar scripts.

When children play together, the embodied texts that children enact are collaboratively created and maintained (Göncü and Kessler 1988) with roles authorized by the group of players. Play actions are made meaningful through interactions when other players recognize them, prompting response from tacit scripts that are sensible to co-players. In this way, the agreed-upon text/context builds upon players' shared meanings; however, play actions that are incongruous with familiar characters or scripts can shift or rupture the context, bringing play to a halt. These breakdowns are catalysts for negotiations and improvised solutions (Sawyer 1997). Improvisation is a creative response to reconcile conflicting identity expectations among cultural contexts (Holland et al. 1998). Thus, play worlds are fueled by cycles of collaboration, negotiation, and improvisation, enabling children to contest and problem-solve as they make decisions on how to enact otherwise automatic and invisible practices while striving to keep play going and to sustain social relationships with peers.

When children play together, they assign, negotiate, and maintain symbolic pretended meanings for objects consistent with the imagined setting. Through improvisation, children test the limits of an object's typical meanings to see how it might be repurposed to represent another idea. If a desired toy is not immediately available, a player can improvise with materials at hand. Players are driven by the intended purpose for a play prop but also consider the iconicity of its physical properties. In one kindergarten play center, a child used a plastic toy carrot as a cell phone because it was small, narrow, and could be handheld. However, the roundness of a plastic apple or orange limits its usefulness as a sign for a phone (Wohlwend 2009). Important to our argument here, the embodied sign created by the physical action of holding an object next to an ear was instrumental in transforming the meaning of the toy carrot to a pretend phone. Children emphasize particular aspects of materials in their motivated signs (Hodge and Kress 1988), choosing materials for their 
sensory qualities to effectively represent their intended meanings and carry out their social purposes. Through play, children learn to detach the conventional meaning attached to a concrete object in the immediate context and reattach a new meaning better suited to their play scenario (Vygotsky 1935/1978). Even very young children access and combine modes and materials into complex semiotic aggregates that enrich and expand meanings but also facilitate considerable social work in the peer culture of the classroom.

\subsection{Future Directions}

Our orientation toward embodiment suggests that novelty and reconfiguration are central to the enterprise, not peripheral. We see novelty and reconfiguration in the play of children and in pedagogical practices that encourage students to create multimodal productions, to write, act, design, dance, and draw. We see it as well in the transnational travel of unfamiliar and uncomfortable semiosis as students across the globe find new ways to communicate with each other. However, while the appeal of creativity is inherent in the idea of redesign of available designs (New London Group 1996) or of genres as social practices that can be mastered and put to use for social and political purposes (Kress 1993), we are not embarking on a critical social project designed to train the habitus of less-privileged students to better match the fields of power and the production of cultural, social, and symbolic capital. Following Luke (1997), we recognize that a pedagogic project focused on habitus, hexis, and the embodiment of communication, so suggestive of emotions, imagination, sensuous and aesthetic, and their connections to more "academic" matters such as cognition and logic, risks going astray unless approached with the utmost theoretical and practical clarity.

Despite this caveat, the study of semiotic embodiment has rich theoretical implications, not only for play and transnational communication but also for the study of hybrid and distance education, both assiduously promoted for reasons of costsavings and access with little theoretical clarity as to the long-term impact of new ways of forming linguistic or academic habitus, and other forms of digital networking that mediate and represent the body in new ways, adding another layer on the diachronic axis of common discourses and genres as they change and adapt to new available designs.

\section{References}

Appadurai, A. 1996. Modernity at large: Cultural dimensions of globalization. Minneapolis: University of Minnesota Press.

Bakhtin, M. 1986. Speech genres and other late essays. Austin: University of Texas Press.

Boldt, G. M. 2006. Resistance, loss, and love in learning to read: A psychoanalytic inquiry. Research in the Teaching of English 40 (3): 272-309.

Bourdieu, P. 1977. Outline of a theory of practice. Cambridge: Cambridge University Press. 
Bourdieu, P. 1991. Language and symbolic power (trans: G. Raymond and M. Adamson). Cambridge: Harvard University Press.

Brougère, G. 2006. Toy houses: A socio-anthropological approach to analysing objects. Visual Communication 5 (1): 5-24.

Carrington, V. 2003. 'I'm in a bad mood. Let's go shopping': Interactive dolls, consumer culture and a 'glocalized' model of literacy. Journal of Early Childhood Literacy 3 (1): 83-98.

Engeström, Y. 1987. Learning by expanding: An activity-theoretical approach to developmental research. Helskinki: Orienta-Konsultit.

Gee, J. P. 1996. Social linguistics and literacies: Ideology in discourses. 2nd ed. New York: Taylor \& Francis.

Ghiso, M. P. 2011. Playing with/through non-fiction texts: Young children authoring their relationships with history. Journal of Early Childhood Literacy 11 (4). doi:10.1177/1468798411430093.

Goffman, E. 1981. Forms of talk. Philadelphia: University of Pennsylvania Press.

Göncü, A., and F. Kessler. 1988. Preschoolers' collaborative construction in planning and maintaining imaginative play. International Journal of Behavioral Development 11 (3): 327-344.

Gumperz, J. 1982. Discourse strategies, 1 vol. New York: Cambridge University Press.

Hanks, W. F. 1996. Language and communicative practices. Boulder: Westview Press.

Hodge, R., and G. Kress. 1988. Social semiotics. Ithaca: Cornell University Press.

Holland, D., W. Lachicotte, D. Skinner, and C. Cain. 1998. Identity and agency in cultural worlds. Cambridge: Harvard University Press.

Hymes, D. H. 1995. Ethnography, linguistics, narrative inequality: Toward an understanding of voice. Washington: Taylor \& Francis.

Jones, R. H. 2005. Sites of engagement as sites of attention: Time, space, and culture in electronic discourse. In Discourse in action: Introducing mediated discourse analysis, eds.S Norris and R. H. Jones, 141-154. New York: Routledge.

Kramsch, C. 2009. The multilingual subject. New York: Oxford University Press.

Kress, G. 1993. Genre as social process. In The powers of literacy: A genre approach to teaching writing, eds.B. Cope and M. Kalantzis, 22-37. Pittsburgh: University of Pittsburgh Press.

Leont'ev, A. N. 1977. Activity and consciousness, philosophy in the USSR, problems of dialectical materialism. Moscow: Progress Publishers.

Luke, A. 1997. Genres of power? Literacy education and the production of capital. In Literacy in society, eds. R. Hasan and G. Williams, 308-337. London: Longman.

Mackey, M. 2007. Literacies across media: Playing the text. Abingdon: Routledge.

Marsh, J., ed. 2005. Ritual, performance, and identity construction: Young children's engagement with popular cultural and media texts. In Popular culture, new media and digital literacy in early childhood, 28-50. New York: RoutledgeFalmer.

New London Group. 1996. A pedagogy of multiliteracies: Designing social futures. Harvard Educational Review 66 (1): 60-92.

Samuelson, B. L. 2009. Ventriloquation in discussions of student writing. Research in the Teaching of English 44 (1): 52-88.

Sawyer, R. K. 1997. Pretend play as improvisation: Conversation in the preschool classroom. Norwood: Erlbaum.

Scollon, R. 2001. Mediated discourse: The nexus of practice. London: Routledge.

Scollon, R., and S. W. Scollon. 2004. Nexus analysis: Discourse and the emerging Internet. New York: Routledge.

Siegel, M., S. Kontovourki, S. Schmier, and G. Enriquez. 2008. Literacy in motion: A case study of a shape-shifting kindergartener. Language Arts 86 (2): 89-98.

Siegel, M., and D. W. Rowe. 2011. Webs of significance. Semiotic perspectives on text. In Handbook of research on teaching the English language arts, eds. D. Lapp and D. Fisher, 202-207. 3rd ed. New York: Routledge.

Steinkuehler, C. A., R. W. Black, and K. A. Clinton. 2005. Researching literacy as tool, place, and way of being. Reading Research Quarterly 40 (1): 90-110.

Street, B. 1995. Social literacies: Critical approaches to literacy development, ethnography, and education. New York: Longman. 
Turner, M. 1996. The literary mind: The origins of thought and language. New York: Oxford University Press.

Vygotsky, L. 1935/1978. Mind in society: The development of higher psychological processes. Cambridge: Harvard University Press.

Wohlwend, K. E. 2008. Play as a literacy of possibilities: Expanding meanings in practices, materials, and spaces. Language Arts 86 (2): 127-136.

Wohlwend, K. E. 2009. Early adopters: Playing new literacies and pretending new technologies in print-centric classrooms. Journal of Early Childhood Literacy 9 (2): 119-143.

Wohlwend, K. E. 2011a. Mapping modes in children's play and design: An action-oriented approach to critical multimodal analysis. In An introduction to critical discourse analysis in education, ed. R Rogers. 2nd ed. Mahwah: Lawrence Erlbaum.

Wohlwend, K. E. 2011b. Playing their way into literacies: Reading, writing, and belonging in the early childhood classroom. New York: Teachers College Press.

Wohlwend, K. E. 2012. The boys who would be princesses: Playing with gender identity intertexts in Disney Princess transmedia. Gender and Education 24 (6): 593-610. doi:10.1080/095402 53.2012.674495.

Beth Lewis Samuelson is an assistant professor of literacy, culture, and language education (LCLE) at the Indiana University School of Education, where she teaches classes in literacy theory and in the English-as-a-second language and World Languages teacher education programs. She is an educational linguist with a strong background in language learning and cross-cultural experience in non-Western contexts. In 2006-2008, she was a Spencer/National Academy of Education Postdoctoral Fellow and a finalist in the 2006 National Council of Teachers of English Promising Researcher award. From 2008 to 2011, she was the faculty advisor to the Books \& Beyond project, a cocurricular service-learning project by the Global Village Living-Learning Center that supports storytelling and book publishing by elementary and middle school students in the USA and Rwanda. Her research interests include language awareness and the flows of English literacy practices across global boundaries. She has interests particularly in understanding the nature of meta-knowledge about language and the role that it plays in critical literacy and language learning.

Karen E.Wohlwend is an assistant professor in literacy, culture, and language education at Indiana University. She reconceptualizes play as a literacy that critically engages the identity texts in toys and games and that expands ways to create meaning and to participate in school. Her publications include a forthcoming book, Literacy Playshop: Playing with New Literacies and Popular Media in the Early Childhood Classroom and a recent book, Playing Their Way into Literacies: Reading, Writing, and Belonging in the Early Childhood Classroom. Her current research critically examines young children's play with toys, filmmaking, and digital technologies in online and classroom spaces. 